chapters to solve ordinary differential equations of the boundary-value and initial-value types. Chapter 8 is mainly concerned with quasi-linear partial differential equations of the second order in two independent variables and uses the method of 'characteristics' for the solution of the hyperbolic equations. The treatment of the elliptic and parabolic partial differential equations is given in Chapter 9, and relaxation methods are discussed in Chapter 10. The last two chapters discuss the various problems which arise in the computation, construction, checking and presentation of numerical tables of mathematical functions. The account is necessarily condensed, but it is supplemented by an extensive and most useful bibliography of reasonably accessible literature.

S. WEINTROUB

The Physiology and Biochemistry of Lactation

By Dr. S. J. Folley. Pp. viii $+153+19$ plates. (Edinburgh and London: Oliver and Boyd, Ltd., 1956.) 18s. $6 d$. net.

$\mathrm{N}$ the past twenty years the Physiology Department 1 of the National Institute for Research in Dairying, under the leadership of Dr. S. J. Folley, has made outstanding contributions to knowledge of the biochemistry and physiology of lactation. The present book is based on a series of lectures given by Dr. Folley at the Collège de France. It presents a commendably clear and readable account of the important advances that he and others have made in the subject, and adequately describes modern methods by which these advances have been achieved. The first of the six chapters discusses the growth of mammary tissue and how it is influenced by œstrogen, progesterone and some of the anterior pituitary hormones. The second and third chapters deal with the initiation and maintenance of lactation, and the fourth with the milk ejection reflex, the nature of the milk ejection hormone and the effector contractile tissue of the mammary gland. The last two chapters describe modern views on the methods by which milk fat, lactose and milk proteins are formed in the gland. The book is well illustrated, the figures and tables are clear and concise, and a valuable list of references accompanies each chapter. It is a book that can be highly recommended to students, lecturers and research workers and indeed to all whose job it is to understand the functioning of the actively secreting mammary gland.

J. A. B. Smith

\section{The Armored Scale Insects of California}

By Howard L. McKenzie. (Bulletin of the California Insect Survey, Vol. 5.) Pp. $\mathrm{v}+209+3$ plates. (Berkeley and Los Angeles : University of California Press ; London : Cambridge University Press, 1956.) 45s. net.

THE wide range of species of the armoured scales, or Diaspididae, to be found in California include many that are primary pests of major agricultural crops. The object of the present work is to enable the thousands of specimens received annually by the State Department of Agriculture to be accurately identified and their occurrence within the State recorded, so that the economic importance of the species may be evaluated. The book, by a well-known authority on this group of insects, is admirably designed to meet this objective.

Keys to genera and species are given as well as excellent detailed figures of each species. The species are not described but the more important taxonomic references are listed and can be consulted where the identity is in doubt. Excellent colour photographs of some of the more important species are included; but it is open to question whether these are of any great aid to recognition, as closely allied forms are often so very much alike in appearance. Type locality and host as well as other known hosts are given for each species as well as other useful informa. tion. There are an index to the genera and species, a host index and a host list including the Diaspidid species, arranged alphabetically under plant families.

This book is very well arranged and brings together a wealth of information that will be invaluable to workers in California. But although it deals with the fauna of a restricted area, many of the species have a very much wider distribution, not only in North America but also throughout the world. It will therefore be of considerable value to all those interested in this group of insects of considerable economic importance.

W. J. HALL

\section{Rocket Propulsion Elements}

An Introduction to the Engineering of Rockets. By George P. Sutton. Second edition. Pp. xii +483 . (New York : John Wiley and Sons, Inc.; London : Chapman and Hall, Ltd., 1956.) 82s. net.

T $T$ is surprising that in spite of the growing importance of rockets since the Second World War so few books have been written dealing with rocket propulsion from the point of view of the design and development engineer. When first published in 1949, this book was the only one of its kind and even to-day it has no equal. This second edition brings the subject up to date and remedies some of the weaknesses of the first edition. The book has been enlarged by approximately 60 per cent and includes new material on both liquid- and solid-propellent motors, the subject-matter of the latter in particular being a considerable improvement on the first edition. A more comprehensive treatment of heat transfer is also included, although radiation could have been dealt with more fully. The many worked examples and the problems at the end of each chapter are useful features although the student would appreciate answers to more of the problems. In a book of this nature covering such a wide field it is inevitable that certain aspects of rocket propulsion cannot be dealt with as fully as some people would wish, and so for those wishing to delve more deeply into specialist subjects there is a greatly enlarged and well-arranged bibliography at the end of the book.

This is a comprehensive technical book covering both the theory and practice of rocket engines and can be thoroughly recommended to all those, whether students or practising engineers, who are concerned with rocket propulsion.

\section{Through Alchemy to Chemistry}

A Procession of Ideas and Personalities. By Prof. J. Read. Pp. xvii +206. (London: G. Bell and Sons, Ltd., 1957.) 18s, 6d. net.

HOSE who have an acquaintance with Prof. Read's earlier books, "Prelude to Chemistry" (1936), "The Alchemist in Life, Literature and Art" (1947), and "Humour and Humanism in Chemistry" (1947), will know how ably and with what charm of style he can draw on his fund of specialized knowledge of the chemistry of the past and the personalities of its practitioners. A new book by him in this field may be expected to be good, and this latest one from his pen amply fulfils expectations. 